dren with cystic dilatation of the biliary cyst and resultant bile stasis. ${ }^{45}$ This would explain the prolonged fever and response to antibiotics.

Ascites, especially as a presenting sign, is extremely rare. It is present in only $15 \%$ of reported cases, and in these it was found only four to 29 years after the patients were first seen. Only in one other case, in the published reports known to us, has ascites associated with congenital hepatic fibrosis been described in early childhood. ${ }^{6}$ The mechanism of ascites in our patient is unclear, especially in the light of normal serum protein concentrations. These two patients show the varied clinical picture of congenital hepatic fibrosis while adding two further presentations to those already described.

We thank the Children's Nutritional Disease Project, Canadian Friends of the Hebrew University, for financial assistance.
References

1 Kerr DNS, Harrison CV, Sherlock S, Milnes-Walker R. Congenital hepatic fibrosis. $Q J$ Med 1961;30:91-117.

2 Alvarez $F$, Bernard $O$, Brunelle $F$, et al. Congenital hepatic fibrosis in children. J Pediatr 1981;99:370-5.

3 Gatrad AR, Gatrad AH. The association of choledochus cyst with congenital hepatic fibrosis. Br J Clin Pract 1979;33:182.

${ }^{4}$ Kocoshis SA, Riely CA, Burrell M, Gryboski JD. Cholangitis in a child due to biliary tract anomalies. Dig Dis Sci 1980;25:59-65.

5 Alvarez F, Hadchouel M, Bernard O. Latent chronic cholangitis in congenital hepatic fibrosis. Eur J Pediatr 1982;139:203-5.

${ }^{6}$ Ghishan FK, Nau S, Younoszai MK. Portal hypertension in a neonate with congenital hepatic fibrosis. South Med J $1981 ; 74: 243-4$.

Correspondence to Professor M Schiller, Department of Paediatric Surgery, POB 12000, Jerusalem 91120, Israel.

Received 26 June 1984

\title{
Plasma C peptide in hyperinsulinaemic hypoglycaemia
}

\author{
M BOMMEN, R STANHOPE, A B KURTZ, AND C G D BROOK
}

Endocrine Unit, Middlesex Hospital, London

SUMMARY We describe two children with hypoglycaemia due to pancreatic beta cell hyperactivity. Both had low serum insulin but raised plasma C peptide concentrations when hypoglycaemic. Measurement of $\mathrm{C}$ peptide is valuable in the diagnosis of hyperinsulinaemic hypoglycaemia in children.

Hyperinsulinaemia is the most common cause of hypoglycaemia presenting in the first year of life after the neonatal period. ${ }^{1}$ Serum insulin should be undetectable during severe hypoglycaemia and this forms the basis for the diagnosis of hyperinsulinism. $^{2}$

$C$ peptide is cleaved from proinsulin in the pancreatic beta cell secretory granules in equimolar quantitites to insulin. $C$ peptide has double the half life of insulin in peripheral blood and only a small proportion of portal blood $\mathrm{C}$ peptide is extracted by the liver, compared with $90 \%$ of insulin. ${ }^{3}$ In addition, the radioimmunoassay of insulin in serum is relatively insensitive at concentrations of $3 \mathrm{mU} / \mathrm{l}$ or below, whereas our $\mathrm{C}$ peptide assay has a more sensitive detection limit of 32 to $50 \mathrm{pmol} / \mathrm{l}$. For these reasons $\mathrm{C}$ peptide is more reliable than insulin as a peripheral indicator of beta cell secretory activity.

\section{Methods}

We have modified the method of $\mathrm{Heding}^{4}$ (available in a kit from Novo Research Institute) for the determination of plasma $\mathrm{C}$ peptide. We have used a double antibody radioimmunoassay and have collected samples in EDTA combined with trasylol. Fasting plasma $\mathrm{C}$ peptide concentration in a normal adult is between 150 and $350 \mathrm{pmol} / \mathrm{l}$ and the lower limit of detection in our laboratory is 32 to 50 $\mathrm{pmol} / \mathrm{l}$.

Case 1. A boy who weighed $2.4 \mathrm{~kg}$ at term presented with convulsions at age 7 months. Early morning lethargy and 'jerking' movements had been observed for two months. A blood glucose concentration of between 0.2 and $1.7 \mathrm{mmol} / \mathrm{l}$ was associated with a serum insulin value of between 8.8 and 69 $\mathrm{mU} / \mathrm{l}$. After a $95 \%$ pancreatectomy, histology and fluorescent polyclonal antibody studies showed the characteristic features of nesidioblastosis. ${ }^{2}$ For three weeks postoperatively he developed temporary diabetes mellitus requiring insulin, in addition to mild steatorrhoea treated by enzyme supplements.

Seven months after the subtotal pancreatectomy he developed a recurrence of morning symptoms, although these were now intermittent. During a 24 hour fast blood glucose values ranged between 1.4 
and $2.1 \mathrm{mmol} / \mathrm{l}$. Although corresponding serum insulins were all less than $2 \mathrm{mU} / \mathrm{l}$, plasma $\mathrm{C}$ peptide was not suppressed and varied between 54 and 192 $\mathrm{pmol} / \mathrm{l}$. Oral glucose tolerance test (Figure) showed a normal fasting blood glucose concentration which rose abnormally by 120 minutes. After the serum insulin had fallen to $2 \mathrm{mU} / \mathrm{l}$ or below, the $\mathrm{C}$ peptide value was greater than $150 \mathrm{pmol} / \mathrm{l}$. Low dose diazoxide treatment has prevented further hypoglycaemia.

Case 2. The daughter of a gestational diabetic was born at term weighing $4.5 \mathrm{~kg}$. After dilutional exchange transfusion for polycythaemia she developed non-ketotic hypoglycaemia which responded to frequent feeds. From the neonatal period she had early morning convulsions which were treated with phenobarbitone. At 1.2 years she was referred to this hospital because of increasing frequency of convulsions and psychomotor delay. After an 11 hour fast her blood glucose concentration fell to $0.8 \mathrm{mmol} / \mathrm{l}$, serum insulin was less than 2 $\mathrm{mU} / \mathrm{l}$ while plasma $\mathrm{C}$ peptide was unsuppressed at $147 \mathrm{pmol} / \mathrm{l}$. A four hour fast before a glucose tolerance test produced hypoglycaemia (Figure). A slow rise in blood glucose occurred with an abnor-
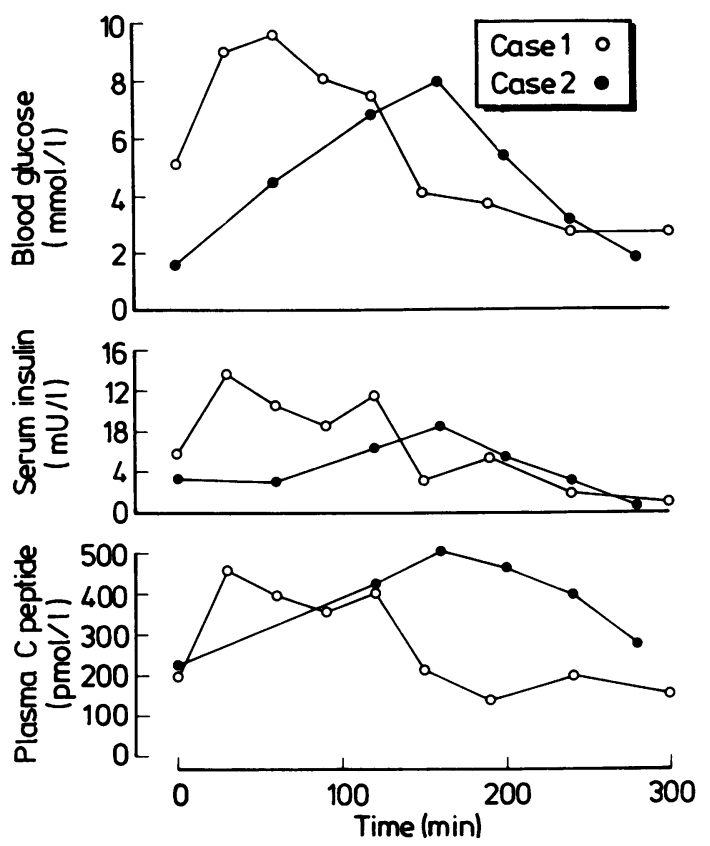

Figure Blood glucose, serum insulin, and plasma $C$ peptide concentrations after an oral glucose load. Both patients were fasted for 4 hours before the administration of $1.75 \mathrm{gm}$ glucose/ $\mathrm{kg}$ body weight at time 0 . mal value at 120 minutes, reaching a peak at 150 minutes. Rebound hypoglycaemia ocurred at 280 minutes with an undetectable serum insulin; her C peptide concentration was inappropriate at 282 $\mathrm{pmol} / \mathrm{l}$. A prolonged trial of high dose diazoxide and chlorothiazide was ineffective and she was treated by $95 \%$ pancreatectomy. Histology showed normal pancreatic architecture and islet cell numbers. Immunofluorescent studies showed normal beta cells. Numerous isolated glucagon and somatostatin cells were seen scattered among the exocrine glands and ducts. Nine months after operation there has been no recurrence of symptoms.

\section{Discussion}

The aetiology of hyperinsulinism includes nesidioblastosis, pancreatic hyperplasia, adenomata, and adenomatosis which may represent a spectrum of the same pathology. ${ }^{5}$ These disorders are clinically and biochemically indistinguishable. ${ }^{6}$ It has been suggested that hyperinsulinism can occur with normal pancreatic morphology ${ }^{6}$ and we suggest that case 2 had a functional beta cell abnormality. The changes seen in the non-beta endocrine cells have been reported in infants of diabetic mothers ${ }^{7}$ and may be compensatory.

Both patients showed that hyperinsulinism can be minimal and intermittent despite beta cell hyperactivity, and that plasma $\mathrm{C}$ peptide values are more reliable than serum insulin in equivocal cases. Buth patients had blunted beta cell responses to glucose loads despite an inability to 'down-regulate' during hypoglycaemia. There was dissociation of the normal relation between blood glucose and insulin secretion. Similar features of beta cell autonomy have been found in tissue cultures of nesidioblastic islets $^{2}$ and this autonomy may be intermittent. ${ }^{8}$

The minimal peripheral hyperinsulinism in both these patients has relevance to the diagnosis of hyperinsulinaemic hypoglycaemia. Measurement of serum insulin alone may be misleading. $C$ peptide in addition to insulin should be measured in cases of suspected hyperinsulinism.

We thank the following at the Middlesex Hospital for their contribution to these studies; Dr R Miriakian, Dr G F Bottazzo, and Professor N Woolf. We are grateful to Professor A AynsleyGreen for his advice in the management of case 2 .

\footnotetext{
References

1 Stanley CA, Baker L. Hyperinsulinism in infants and children; diagnosis and therapy. Adv Pediatr 1976;23:315-55.

2 Aynsley-Green A, Polak JM, Bloom SR, et al. Nesidioblastosis of the pancreas: definition of the syndrome and the management of the severe neonatal hyperinsulinaemic hypoglycaemia. Arch Dis Child 1981;56:496-508.
} 
${ }^{3}$ Horwitz DL, Kuzuya H, Rubenstein AH. Circulating serum C-peptide; a brief review of diagnostic implications. $N$ Engl J Med 1976;295:207-9.

${ }^{4}$ Heding LG. Radioimmunological determination of human C-peptide in serum. Diabetologia 1975;11:541-8.

${ }^{5}$ Heitz PU, Kloppel G, Hacki WH, Polak JM, Pearse AGE. Nesidioblastosis: the pathologic basis of persistent hyperinsulinaemic hypoglycaemia in infants. Diabetes 1977;26:632-42.

- Pagliara AS, Karl IE, Haymond M, Kipnis DM. Hypoglycaemia in infancy and childhood. Part II. J Pediatr 1973;82:558-77.
${ }^{7}$ Milner RDG, Wirdnam PK, Tsawakas J. Quantitative morphology of B, A, D and PP cells in infants of diabetic mothers. Diabetes 1981;30:271-4.

${ }^{8}$ Hollands E, Giron BJ, Reyt F, Dutrillaux MC. Insulin secretion by human pancreas cultured for one year. J Physiol (Paris) 1976;72:815-32.

Correspondence to Dr C G D Brook, The Middlesex Hospital, London W1N 8AA.

Received 28 June 1984

\title{
Neonatal fat embolism and agglutination of Intralipid
}

\author{
M Z MUGHAL, M J ROBINSON, AND W DUCKWORTH \\ Departments of Neonatal Medicine and Biochemistry, Hope Hospital, Salford
}

\begin{abstract}
SUMmary Pulmonary fat embolism in a preterm infant receiving Intralipid intravenously is described. Serum obtained at the time of clinical deterioration agglutinated Intralipid. This coincided with the onset of septicaemia and with a raised serum $C$ reactive protein concentration. Subsequent clinical improvement was associated with reduction in the $\mathrm{C}$ reactive protein concentration and nonagglutination of Intralipid.
\end{abstract}

Intravenous infusion of Intralipid (Kabi-vitrum) has been widely used as a calorie rich supplement and a source of essential fatty acids in intravenous feeding regimens for neonates. ${ }^{1}$ Fat embolism, however, has been found at necropsy in the lungs of infants who have died while receiving intravenous Intralipid. ${ }^{2}$ Hulman $e t a l^{4}$ noted that serum of ill adult patients with a raised concentration of $\mathrm{C}$ reactive protein agglutinated Intralipid in vitro and have suggested that this is the mechanism for lipid microembolisation in vivo.

\section{Case history}

A boy weighing $800 \mathrm{~g}$ was born vaginally at 26 weeks' gestation. He developed hyaline membrane disease requiring intermittent positive pressure ventilation and thereafter required prolonged mechanical assistance for apnoea. The infant was fed parenterally via peripheral veins using a mixture of $10 \%$ Intralipid; Vamin-Glucose (Kabi-vitrum); and $10 \%$ dextrose with electrolyte, trace metal, and vitamin additives. Intralipid was administered by continuous infusion over 20 hours using a syringe pump. Fat intake was initially started at $0.5 \mathrm{~g} / \mathrm{kg} /$ day and subsequently increased to a maximum of 4 $\mathrm{g} / \mathrm{kg} /$ day. Serum was examined visually four hours after stopping Intralipid infusion to confirm clearance of Intralipid.

While on continuous positive airways pressure on day 41, the infant's general condition deteriorated; there was temperature instability and an increase in oxygen requirement for which intermittent positive pressure ventilation was instituted. At the time, fat globules were identified in a tracheal aspirate on Sudan III staining. Pulmonary lipid microembolisation was suspected and intravenous feeding was stopped. Naso-jejunal feeds were introduced cautiously after 48 hours. Blood cultures taken at the time of the deterioration grew Candida albicans and treatment with intravenous amphoteracin and miconazole was begun. There was rapid improvement in the child's respiratory status, with reduction in both the oxygen requirement and the need for ventilatory support, and by day 49 he was extubated into an oxygen enriched environment.

Blood was drawn on days $14,41,45,48$, and 54 of life. The serum concentration of $C$ reactive protein was assessed using rocket immunoelectrophoresis technique. ${ }^{5}$ Ten $\mu$ l of Intralipid $10 \%$ was incubated at $37^{\circ} \mathrm{C}$ with $200 \mu \mathrm{l}$ of serum and the mixture was inspected after 24 hours for visual and microscopic evidence of agglutination. ${ }^{4}$ The findings are displayed graphically in the Figure. The serum concentration of $C$ reactive protein was $2 \mathrm{mg} / \mathrm{l}$ on day 14 ; on day 41 at the time of clinical deterioration and the observation of fat globules in the tracheal aspirate the concentration was $150 \mathrm{mg} / \mathrm{l}$. The candida septicaemia responded to treatment and the concentration of $\mathrm{C}$ reactive protein fell steadily to 7 $\mathrm{mg} / \mathrm{l}$ on day 54 . Serum obtained when the child was ill and when the $\mathrm{C}$ reactive protein concentration 